IZA DP No. 8751

Growth and Poverty in Africa:

Shifting Fortunes and New Perspectives

Abebe Shimeles

December 2014 


\title{
Growth and Poverty in Africa: Shifting Fortunes and New Perspectives
}

\author{
Abebe Shimeles \\ African Development Bank \\ and IZA
}

Discussion Paper No. 8751

December 2014

\author{
IZA \\ P.O. Box 7240 \\ 53072 Bonn \\ Germany \\ Phone: +49-228-3894-0 \\ Fax: +49-228-3894-180 \\ E-mail: iza@iza.org
}

Any opinions expressed here are those of the author(s) and not those of IZA. Research published in this series may include views on policy, but the institute itself takes no institutional policy positions. The IZA research network is committed to the IZA Guiding Principles of Research Integrity.

The Institute for the Study of Labor (IZA) in Bonn is a local and virtual international research center and a place of communication between science, politics and business. IZA is an independent nonprofit organization supported by Deutsche Post Foundation. The center is associated with the University of Bonn and offers a stimulating research environment through its international network, workshops and conferences, data service, project support, research visits and doctoral program. IZA engages in (i) original and internationally competitive research in all fields of labor economics, (ii) development of policy concepts, and (iii) dissemination of research results and concepts to the interested public.

IZA Discussion Papers often represent preliminary work and are circulated to encourage discussion. Citation of such a paper should account for its provisional character. A revised version may be available directly from the author. 


\section{ABSTRACT \\ Growth and Poverty in Africa: Shifting Fortunes and New Perspectives ${ }^{1}$}

Growth has been high and widespread in the last decade in Africa. Whether this shift in Africa's fortune has impacted poverty has been a subject of controversy. This paper brings into focus recent evidence on the pace of poverty reduction in Africa and addresses whether or not previously held belief that Africa is too poor to grow is relevant today. The findings suggest that there is credible evidence for poverty to have declined significantly since the 1990 s but at a lesser speed than growth in per capita GDP. More importantly, global poverty tends to respond much more strongly to shifts in sector of employment, particularly to increase in employment in the industrial sector, than to increase in mean income. In Africa the co-existence of a large traditional and informal sector with a dynamic modern sector will continue to pose a challenge for achieving a sustained reduction in poverty. Challenges of structural transformation and its attendant benefits are discussed using emerging thinking on industrial policies to achieve inclusive growth in Africa.

JEL Classification: $\quad 012$

Keywords: economic growth, poverty traps, multidimensional poverty, structural transformation

Corresponding author:

Abebe Shimeles

African Development Bank

P.O. Box 323

1002 Tunis-Belvédère

Tunisia

E-mail: a.shimeles@afdb.org

\footnotetext{
${ }^{1}$ Part of this paper is forthcoming in The Oxford Handbook of Africa and Economics, edited by Célestin Monga and Justin Yifu Lin, Oxford University Press. I thank Celestin Monga for extensive and useful comments. I express my gratitude to Tiguene Nabassaga, African Development Bank, for excellent research assistance. I remain responsible for all errors in the paper. The views expressed in this paper are that of the author, and not that of the African Development Bank Group and its Board of Directors or the countries they represent.
} 


\section{Introduction}

The first decade of the new millennium ended well for Africa as compared to the previous 'lost decades' where per capita incomes stagnated or declined in most countries. With the growth trajectory of the early decades reversed, Africa's macroeconomic performance is celebrated globally. Leading media outlets such as The Economist $(2013,2011)$ punctuated Africa's recent growth performance with "Africa Rising", "Africa Emerging" in sharp contrast to "Hopeless Africa" it chronicled in early 2000. Others like McKensie (2010) produced a report that heralded the beginning of new era in Africa. Indeed Africa has produced contrasting growth narrative that clearly challenges prevailing view and analysis on its economic prospect. Has this shift in the growth trajectory of Africa been translated into sustained and comparable reduction in extreme poverty? The answer depends very much on how poverty is conceptualized and measured. There are two contending views on the path of poverty in Africa whose key difference lies in whether mean per capita income in a country should be drawn from national accounts or household surveys (Deaton, 2005). The common approach promoted mainly by World Bank is to draw distributional information and average welfare levels (per capita income or per capita consumption) from household budget surveys to compute income-based poverty. As a result, nearly all official poverty statistics reported by national governments in Africa are based on information drawn from household surveys. According to this approach poverty in Africa, defined as the percentage of the population earning an income level below 1.25 dollar a day per person, has been declining slowly (McKay, 2013; Page and Shimeles, 2013). Africa is considered 'the last frontier' in the fight against extreme poverty in the world. In early 1980s, Sub-Saharan Africa had the lowest levels of extreme poverty compared to Latin America, East Asia and South Asia. At the end of the 2000 decade however, it had the highest rate of extreme poverty among these regions (Figure 1).

\section{$<$ Figure 1 here >}

On the other hand, Pinkovskiy and Sala-i-Martin $(2014,2013)$ argue that survey-based methods have overstated initial poverty and understated the pace at which it has declined over time. In their approach, which is based on mean income drawn from national accounts, initial poverty in Sub-Saharan Africa in 1990 was around 34\% and declined steadily in 2010 to around $21 \%$ at a rate of almost $2 \%$ per annum. The true extent of poverty in Africa would probably continue to be 
a controversial issue. However, what is evident is that, extreme poverty in Africa, particularly Sub-Saharan Africa, is still a major challenge that may have to be seen from the perspective of sustainability of the current growth spurt and transformation of sources of livelihoods in future.

Much has been written in the last decade on persistence of poverty, household assets and other indicators of wellbeing in Africa ${ }^{2}$. The most widespread and contentious narration is whether African countries are confronted with initial conditions that seemingly make sustained reduction in poverty an insurmountable task without meaningful positive exogenous shock, such as foreign aid, foreign direct investment, or other sources of development finance. The assertion begun with the analysis of why Africa is growing slowly or not at all, with some attributing it to the hazards of bad climate and geography (e.g. Sachs and Warner, 1997); anti-growth syndromes of different origins, such as bad policy, chronic corruption, etc, (Fosu , 2009); artificial boundaries (Alesina et al., 2007); conflict (Collier, 2004; Andrimihaja et al, 2012), and even system of slavery in pre-colonial periods (Nunn, 2008). These studies implicitly or explicitly suggest that most African countries are too poorly endowed to grow and are locked in low income equilibrium trap (Sachs et al, 2007). The connection between growth and poverty is self-evident; without growth a sustained reduction in poverty and wealth creation is not feasible.

There is enough evidence to suppose that the growth narrative has changed, and the poverty numbers seem to be improving over time. The question remains would African countries be able to sustain these gains? What steps should be taken to prevent growth collapse and rise in poverty? Has the current growth episode been accompanied by sufficient momentum in job creation? These are the issues most policy makers and development partners ponder in contemporary Africa. Thus, the quest for 'inclusive' growth is now full steam in many countries. Against this background, this paper attempts to provide perspective on the lingering issue of poverty traps (or reversal of fortunes) implied by most analytics and empirics, and addresses the potential for growth to affect poverty on a sustainable basis. The rest of the paper is organized as follows: section 2 presents the theoretical basis for poverty traps in the context of Africa, with balanced review of the evidence, section 3 discusses the link between growth and poverty, and Section 4 outlines the future policy shaped by the emerging reality, and section 5 concludes.

${ }^{2}$ e.g. see. McKay, 2013; Booysen et al., 2008; Sahn and Stifel, 2000 


\section{Is poverty entrenched in Africa?}

Economic theory attributes self-reinforcing poverty due to either market failure or bad institutions (Azariadis and Stachurski, 2005) ${ }^{3}$. Neo classical growth theory predicts that if markets and institutions perform well, then, poor countries should be able to grow faster than richer countries due to diminishing returns to capital. That is, return to capital would be consistently higher in low income than in high income countries. However Sachs et al (2007) argued that in the case of African countries, particularly in Sub-Saharan Africa (except South Africa) the assumption of high returns to capital is unrealistic in an environment where basic infrastructure (road, power, human capital) is nearly non-existent. There is minimum threshold of capital needed before self-reinforcing growth can be realized. This non-convexity in production functions generates two types of economies: one that perpetually grows, and another that experiences growth collapse. Africa is in the latter category. The implications of such characterization of African economies as articulated in Sachs et al is that massive injection of capital in the form of aid is needed before these economies are ready for take-off. This is indeed a resurrection of the Big-Push approach that justified for development assistance in the 1950s.

The assertion African countries are too poor to grow sparked research to investigate the empirical basis of its predictions and assumptions. Easterly (2006) undertook extensive documentation of growth performance of African countries between 1950-2001 finding no basis for zero per capita growth in the long term, which is the empirical implications of the poverty trap hypothesis. Similarly Kraay and Raddatz (2007) could not find evidence of poverty trap using a canonical neo-classical model along the lines of Sachs et al (2007) for African countries. On the other hand, Berthlemy (2006), based on semi-parametric estimate of growth dynamics for individual African countries reported prevalence of poverty traps for most countries where growth episodes remained cyclical reverting to initial per capita levels ${ }^{4}$. Table (1) updates Easterly (2006) and reports per capita GDP growth for countries who were in the bottom quintile in 1962 by setting them as dummies for three overlapping periods: 1962-2011; 19621995; and 1995-2011 covering 42 countries for which we have balanced data for the entire period. In the long term, if initially poor countries grow slower than the 'rest', then, there is a

\footnotetext{
${ }^{3}$ For an example of theoretical models that describe different mechanisms by which poverty traps may result see for instance Lopeza et al (2011), Goodhand et al. (2007) and Ghiglino, and Sorger (2002)

${ }^{4}$ See also Cazzavillan, et al., (2013) for a recent evidence on poverty trap using cross-country data
} 
'sign' that initially poor countries may be 'stuck' in low-income equilibrium, with no potential of catching up with the relatively 'richer' countries, which is the prediction of a self-reinforcing low income trap or poverty trap. The table indicates that for all periods examined countries that had started out as poor in 1962 have been growing at a faster rate than the rest of the 'better-off' group. This trend is unchanged by looking at structural breaks as well, where during 1960-1995 Africa on the whole experienced a downward trend in the growth episode and recovered since then. This evidence poses a challenge to the idea of stagnant per capita GDP for the poorest countries and at least at the macro level there is no visible poverty trap and the neo-classical predictions of conditional convergence seems to be at work.

$<$ Table 1 here>

The poverty-trap studies at the macro level generally focused on dynamics of per capita GDP growth in a cross-country context finding on balance that countries with low initial level of per capita income grow faster than those with high per capita income. Even among African countries, nearly all growth regressions indicated existence of conditional convergence in incomes. If this is true then, such process should also imply a convergence in poverty levels as growth necessarily leads to lower poverty.

Recent studies have shown a contrary result. For instance, Lopez and Servén (2009) and Ravallion (2012) using a sample of developing countries reported that high initial poverty would hinder growth. This is a very important result that could have serious implications mainly to most countries in Africa which have high incidence of initial poverty. The mechanism by which this empirical regularity is explained is along the lines of the theory of poverty trap alluded to above. As new and reliable data sets become available, or sub-samples are used, the empirical results may change. For example, for the Africa sub-sample using Ravallion's data set, Shimeles and Thorebecke (2014) found that high initial poverty does not seem to affect growth. A much more disaggregated and large survey data is needed to unpack results of the cross-country narrative.

Studies that used micro data in Africa are suggestive of existence of poverty traps in line with Lopez and Servén (2009) and Ravallion (2012). One of the most common causes of poverty traps in Africa is a situation where credit or borrowing constraint coupled with income risk could 
make an initially poor household or an individual to remain poor for an extended period (Dercon, 1998; Barrett and Swallow (2006); Barnett and Barrett, 2008; Santos and Barrett, 2011). This is not surprising. Subsistence farmers in rural areas in most African countries lead precarious livelihood (exposed to income risk due to shocks), and have no access to financial services to invest in high return activities. As a result, those who are already poor are unable and unwilling to undertake risky and costly investments that could have higher future returns. Dercon's (1998) work in rural Tanzania showed that poor people would not engage in cattle rearing even though this particular activity had a high potential for wealth accumulation. The reason is that poor households had no access to credit to finance initial cost of acquiring cattle and due to income risk they could not save enough to self-finance as they would have to smooth consumption in time of shocks. Without external intervention, livelihood for initially poor households would propagate poverty. Similarly, major but short-lived shocks, such as natural disaster (drought, crop failure, illness etc), conflict, and political instability would lead to persistence of the shocks for a long time. Studies by Dercon (2006), Dercon and Christiansen (2011), Bigsten and Shimeles (2008) for Ethiopia, Giesbert and Schindler (2012) for Mozambique, Carter et al(2007) for Ethiopia and Honduras; Radney et al (2012) for Kenya and other studies showed the existence of path dependence in the incidence of poverty at the household level ${ }^{5}$. The body of work based on micro data seems to support the finding that some livelihood systems in Africa, particularly farming and informal activity are prone to self-reinforcing poverty ${ }^{6}$.

While it is possible for a country at a macro level to experience faster growth over extended period of time, a large segment of its population thriving in farming, small scale informal activities and other labor intensive activities could be mired in poverty traps. This is the reality most low income African countries are confronted with. This partly may explain the apparent inconsistency between high economic growth and low pace of poverty reduction, which is the subject of the next section.

\footnotetext{
${ }^{5}$ See for instance Naschold (2012) reported existence of poverty traps for households in India living in semi-arid areas

${ }^{6}$ The body of work that focused on investigating poverty traps at the household level is still evolving. There are studies that reported of finding no poverty traps in the African case as well (e.g. McKay and Perge, 2011). However at least there is strong evidence from household panel surveys of multiple rounds that there is a 'true' state dependence in the evolution of poverty and poverty spells, which suggest the persistence of poverty following short-lived shocks.
} 


\section{Growth, poverty reduction and wealth creation}

It is established fact that economic growth has been high in most African countries in the past decade. The prevailing view that African countries are too poor to grow is increasingly challenged by these recent trends. Some may argue that the recent growth spurt is nothing else but a recovery of the ground that has been lost in previous decades (e.g. Larke and Milanovic, 2013). It is true that Africa experienced significant growth regression during the 1970s, 80s and early 1990s. However, the growth experienced in recent decades was more than a recovery and per capita GDP levels have been much higher than they were in early decades (see Figure 2).

\section{$<$ Figure 2 here>}

In fact, there is evidence suggesting that recently widespread growth acceleration has taken place unprecedented for decades. Following the definition of growth acceleration by Hausmann, et al. $(2005)^{7}$, Figure 3 provides the proportion of countries that have completed growth acceleration in a space of five years since the 1960s. According to the Figure, during the early years of 1960s there was no African country that registered a growth episode that could be labeled as a growth acceleration based on the definition adopted here. During 1966-1971, 15\% of the 48 countries for which data was available had at least one growth acceleration. Since then, the proportion of countries having completed growth acceleration in a space of five years started to decrease at a rapid rate reaching a bottom of $2 \%$ in the early 1990s. Then, things started to improve and in the early part of 2000 , close to $23 \%$ of African countries from the same sample completed growth acceleration. It is also important to note that only 8 countries completed multiple growth accelerations in the last 45 years indicating the challenge Africa as a whole faces in sustaining rapid growth over an extended period. Still, the recent improvement may not be underestimated.

\section{<Figure 3 here>}

What is not very clear is whether poverty has been declining and wealth widely distributed corresponding to the high growth experienced by many countries. It is difficult to provide conclusive evidence to the link between growth and poverty. Most African countries undertake

\footnotetext{
${ }^{7}$ A country is said to have experienced episode of growth acceleration if the following three conditions are met: a) per capita GDP has grown at a rate of at least $3.5 \%$ or more, b) growth acceleration (the rate of growth in per capita GDP growth during the same period ) is at least $2 \%$ c) per capita GDP at initial period is higher than the last period in the growth episode.
} 
household surveys in intervals of three to five years, and often with no regard to comparability and consistency of survey designs (Deverajan, 2012). Thus, one has no option but to patch up the evidence from fragments of individual surveys collected in different periods. The most widely used data by researchers is that provided by World Bank in its website www.povcalnet.org where 'official' income distribution data is available for a large number of African countries for the period 1981-2010 ${ }^{8}$. The evidence from this data as shown in Figure 1 for Sub-Saharan Africa does suggest that poverty has declined only by about 5 percentage point in the last decade or by about $1 \%$ per annum. When one compares with the per capita growth rate of close to $2.5 \%$, the pace of poverty reduction is low. This evidence is consistent with other studies that used unit record data for selected African countries for two or more waves (e.g. Page and Shimeles, 2013). It is important to point out that alternative approaches that rely on a combination of national accounts (to estimate mean income) and surveys (to estimate distribution of income) have reported a rapidly falling poverty in the last two decades (e.g. Pinkovskiy and Sala-i-Martin , $2014 ; 2013)$. These estimates suggest a fall in poverty at a rate of $1.9 \%$ per annum, almost double to that obtained from household surveys.

The other piece of evidence that may shade light on growth and poverty reduction could be obtained from the Demographic and Health Surveys (DHS) that document household wealth or asset in great detail, and comparable across a large number of countries in multiple waves. Based on this data set, Young (2012) reckons that per capita consumption on the average has increased at a rate of $3.5 \%$ to $3.7 \%$ in the last two decades in Africa. This implies that on average most African countries might have grown at a rate of $7 \%$ in the last two decade. During this period, Ncube and Shimeles (2013) using DHS data reported that the size of the middle class increased in 21 of the 25 countries that had multiple waves (Figure 4).

\section{<Figure 4 here>}

Some countries like Senegal, Ghana and Kenya achieved rapid increase in the size of the middle class, but others have made slight improvements. The average change in the size of the middle class between the 1990 decade and the 2000 decade was about 3 percentage point or a rise from $7 \%$ to $10 \%$. This is not comparable to the average expansion in African economies Young (2012)

\footnotetext{
${ }^{8}$ This poverty data is currently under revision using the results of the recent Purchasing Power Parity data from the International Comparison Program, which may significantly affect the trend reported here.
} 
reported using similar data sets. In addition, if we examine the possibility of transiting into a middle class from being poor in terms of wealth, the picture we get is not encouraging. Table 2 presents transition matrix based on a synthetic panel constructed from a large number of African countries in multiple waves using time-invariant characteristics such as age and sex as a cohort. What emerges is that there was only a 5\% probability for a household that was asset poor to transit into a middle class status and vice versa. There is a clear persistence of class over time. Similarly, those that started out as a middle class in pre-1995 had a 70\% probability of remaining middle class and very small chance of slipping back into poverty. Actually they had a better chance of moving up into an upper class over time. On the whole, the probability of being asset poor at any time was around $87 \%$ which still is extremely high incidence when one takes into account housing conditions, household utilities, and other indicators of wealth.

$<$ Table 2 here >

The DHS data could also be used to construct a multidimensional measure of asset-based poverty that may provide additional insight into the evolution of household welfare through access to a wide range of amenities and utilities. Table (3) reports the trend in asset-based poverty constructed on the basis of access to nine household amenities and utilities, including type of housing (roof-top and floor); clean water, electricity, and toilet; ownership of household durables such as radio and television. By our definition, households who live in houses with a grass roof-top and mud floor, no access to clean water, electricity, toilet, and do not own radio or television are classified as poor. The table reports asset-based multidimensional poverty for a block of four periods since very few countries had their surveys in the same year. The results bear some similarities with both national accounts and survey based estimates of poverty. It is remarkably similar with estimates by Pinkovskiy and Sala-i-Martin $(2014 ; 2013)$ in its range of poverty estimate between the end periods (pre-1995 and 2005-2011). On the other hand, the pace of poverty reduction stalled or declined very slowly after 1995 still echoing the pattern in the survey based estimates of poverty.

$<$ Table 3 here>

To examine the link between the asset-based poverty measures and (long-term) growth, Figure (5) provides a simple correlation between poverty and log of per capita GDP from World Penn 
Tables. The implied elasticity is approximately -0.94 , that is, if per capita GDP rises by $1 \%$ then, poverty might fall by about $0.94 \%$, which is close to unity. This result is closer to earlier estimates on growth elasticity of poverty for Africa (UNECA, 1999; Dollar and Kraay, 2002). The corresponding elasticity implied by the poverty trend in Pinkovskiy and Sala-i-Martin (2014; 2013 ) is about -1.3 . That is, a $1 \%$ growth in per capita GDP would lead to more than $1 \%$ decline in poverty, which is higher than most available estimates. Analytical derivations have shown that the growth elasticity of poverty is mainly driven by the level of initial development, initial inequality and the position of the poverty line in the distribution of income (Bourginon, 2002; Bigsten and Shimeles, 2006). Poorer countries with high initial inequality may find harder to attain rapid reduction in poverty through growth alone.

\section{$<$ Figure 5 here $>$}

One of the reasons why growth might not lead to significant reduction in poverty may have to do with the sectoral composition of growth and employment. From Table 4 it is easy to infer that in Africa, close to $85 \%$ of poverty originates either in agriculture $(54 \%)$ or services $(31 \%)$, and the poverty impact of growth depends on what has happened to these sectors in the last decade.

<Table 4 here>

Furthermore, as extreme poverty rises, the gap in poverty between those employed in agriculture widens in comparison to those in industry or services (Figure 6). For some poor countries, bringing poverty levels in the agricultural sector down to those in services and industry would take them a long way in dealing with extreme poverty. The picture we get for most African countries is a clearly dichotomous economy where on the one hand higher level of poverty in agriculture co-exists with relatively low poverty in the industrial sector. In the extreme case where poverty is rampant, it does not matter which sector of the economy one is employed. Almost everyone is poor.

$<$ Figure 6 here $>$

The importance of structure of employment, rather than average growth in per capita GDP for impacting significantly on poverty is illustrated in Table 5. It shows that for a sample of developing countries, extreme poverty responded much strongly to industrialization (or rise in 
employment in the industrial sector) than to average growth in per capita incomes. A one percent increase in the share of employment in industry could lead to a 0.7 percent decrease in poverty. On the other hand, a one percent increase in per capita GDP was associated with only a 0.3 percent reduction in poverty. The picture for the sample of African countries is different. Structure of employment in agriculture and services had a rather poverty increasing effect (though the associated coefficient was significant at 10 percent), and no statistically significant effect was observed for changes in employment in the industry sector. This result is not surprising. Few countries had rising industrial employment in Africa. The fact that the developing world has managed to significantly reduce extreme poverty in the last decade, and that this achievement is mainly driven by shifts in the structure of employment than in growth in average incomes sends a clear message to African countries that have still a long way to go in fighting poverty.

$<$ Table 5 here>

\section{Implications to development policy}

Despite encouraging growth and falling poverty, Africa still harbors a significant share of its population living in extreme poverty. A typical African country may not be in a poverty trap at the macroeconomic level. Positive exogenous shocks such as improvements in terms of trade, particularly the steady rise in the prices of commodities, increase in the flows of FDI and remittances, and better macroeconomic management, all contributed to reviving growth and spreading it across many countries in Africa in the last decade. On the other hand, progress in poverty and wealth creation is not keeping pace with the growth story. It is changing very slowly and it is worrying, particularly in light of recent findings that high initial poverty may hinder growth.

The obvious reason why poverty is not declining faster lies in the fact that fast growing sectors do not employ many people, and sectors that do employ many people have not been growing faster. Until recently, Africa has not seen structural change as drivers of growth rather than increase in productivity in the small, but dynamic modern sector (McMillan, 2013). The challenge for African countries, as well as their development partners is to figure out how to set in motion structural change in their economies and what are the policy options available. 
One of the recognizable, but less emphasized defining characteristics of most African economies is that they have a traditional sector that has been a mainstay of the bulk of the population for generations, and a modern sector that evolved in recent decades through urbanization and process of natural resource extraction. These two economic systems are governed by a completely different set of technology, incentive structure, risk, access to resources and infrastructure (Monga, 2013) ${ }^{9}$. Yet, the overwhelming policy orientation in the past two decades that govern the whole economy, including the traditional sector has been the neoliberal approach that focuses on getting fundamentals right and everything else falls into place. Early development economists on the other hand made a point that to spur growth in a dual economy setting labor has to move away from the traditional to the modern sector. That is structural change is the driving force for economic growth.

In this connection, Rodrik (2013) argues that both the neo-classical growth model and the structural change approach to development in a dual economy setting complement each other and he outlined a development framework that combines the two approaches. In his approach, countries will grow fast and sustain growth if they deepen reform in getting fundamentals right and also promote structural change in their economy with sector specific programs, such as industrial policy. A focus in one, with a neglect of the other would lead to sub-optimal growth trajectory. In his typology, Rodrik outlines that countries that focus and invest less in economic fundamentals (improved governance, macroeconomic management, openness, rule of law, property rights, better investment climate, etc), and also less in promoting structural transformation (industrial policy, subsidies of specific sectors, infrastructure and technology investment, rural transformation, etc.) will have no growth at all. Similarly, countries that invest on fundamentals, but fail on structural transformation could only see episodic growth that is not sustainable. Those that do very well in improving economic fundamentals, but are slow in promoting structural transformation grow only slowly, etc. In terms of priorities, improving the fundamentals of the economy is a necessary condition for achieving sustainable growth. The policy sequences and implementation strategy that echo Rordrik's typology is described at great length in Li and Monga (2011). Poor countries intent to break vicious circle of poverty on a sustainable basis will have to make a conscious effort to learn from the experiences of countries

\footnotetext{
${ }^{9}$ Paternostro (1997) outlined the poverty trap underlying a dual economic system such as described here.
} 
that have had similar endowment structure, take concrete actions to remove constraints that prevent existing firms with similar economic structure from upgrading their technologies; or if such firms do not exist in the domenstic economoy pursue ways and means of creating them; pay due attention to potential innovations by private enterprises for scaling up and replication, etc. In short, Li and Monga (2011) emphasize the role of the state in forging structural change in poor countries. .

Policy makers in Africa and their development partners may need to pay heed to this emerging new policy orientation. Recently, Page and Shimeles (2013) argued that for development aid to have stronger impact on employment and poverty, it should focus on activities that promote structural transformation. In their review of the trend of development assistance in the last two decades, there has been a clear shift away from 'productive' sectors to financing 'social or nonproductive sectors'. In addition, most policy makers in low income countries have withdrawn their effort to modernize their economy, leading in some instances to a process of deindustrialization, particularly during the era of Structural Adjustment Programs. There has been some effort in early 2000 by the World Bank to revive the making of industrial policy in Africa through government-private sector dialogue using the East Asia model. A synthesis of the case study of Ethiopia, Senegal, Tanzania and Uganda by Page (2013) on Presidential Advisory Council that was set up with the support of the World Bank revealed that the process has created a useful forum for the government to understand the key practical constraints investors face, and agree on specific measures. Except for Uganda, so far the influence of these councils in facilitating bold and experimental undertakings that push the agenda of industrialization is questionable. Currently there is a wide recognition on the need for industrial policy, but, governments in Africa need a practical guide on how best to intervene to kick-start the process. In their extensive discussion, Stiglitz, et al (2013) outlined useful framework to implement industrial policy with a view of initiating structural transformation where they focused on how to deal with issues of coordination failure, externalities and other 'hard' and 'soft' infrastructure needed for a process of unfettered industrialization.

Structural transformation is not only about industrialization. It is also transforming the traditional sector through a set of policies that reduce income risk, provide access to modern technology, financial services and market in order to increase productivity in the sector. There are a number 
of programs in several African countries that are designed to transform the rural economy and small businesses in urban areas. The success of such programs reduces the risk of selfreinforcing poverty conditions that are reported in a number of countries.

Finally, investment in health and education, apart from playing an important role in breaking the poverty trap, also assists in reducing wealth and income inequality. Figure 7 illustrates a strongly declining wealth inequality as a country's mean level of education rises. In poor countries, differences in educational attainment are one of the key drivers of differences in observed inequality, particularly at higher level of education. For instance, Ncube and Shimeles (2013) reported that the role of education in explaining the variance in wealth status of households exceeded $25 \%$ in 30 of the 83 regression decompositions they had undertaken. Not only that, the 'returns' to education in terms of asset or wealth acquisition was always higher for those who completed either tertiary or secondary education in comparisons to those individuals with no education across the entire spectrum of educational achievement. This is one of the neglected areas in most parts of Africa. The rise of educated unemployed speaks for the mismatch between demand and supply as well as the quality of education (African Economic Outlook, 2012). The same also applies with respect to inequity in health (e.g. Moradi and Baten, 2005) ${ }^{10}$.

$<$ Figure 7 here>

\section{Conclusion}

Development Economics has pushed the boundaries in the last four decades by providing the analytical foundations to understand poverty and its link with economic growth. Poverty statistics is now routinely reported by national governments and development agencies to monitor its incidence and severity. As the discussion in this paper indicated, average growth in the economy may be necessary but not sufficient to affect significantly the pace of poverty reduction. The pattern and source of growth remains important. Particularly, coexistence of persistent poverty among self-employed in the rural traditional and urban informal sectors with a modernizing and rapidly growing modern sector puts structural transformation at the center stage of development policy for African countries. The evidence for a sample of developing countries

\footnotetext{
${ }^{10}$ See also Kalwij and Verschoor, (2007) for a further discussion of vagaries of inequality
} 
suggest that extreme poverty can be dealt better by moving labour from low to high productivity sectors.

The last decade has witnessed shift in the fortunes of most African countries where per capita incomes have been steadily rising for the first time in decades. The corresponding effect on poverty however has been less clear and controversial. This is worrisome for a continent that still harbors a very large segment of its population mired in abject poverty. Most African countries indeed have seen a rise in the middle class and some reduction in poverty. On the other hand, poverty is also deeply entrenched. The urgency for rethinking and calibrating policy options cannot be overemphasized.

The future if harnessed properly favors Africa. It is the only continent where its labor force is young and is growing offering it an opportunity known as the "demographic dividend" at the time when the global labor market might face an excess demand. In addition, there is a natural resources boom in nearly 45 African countries whose potential revenue to the government coffers is in the order of $150 \%$ of current GDP of the continent. These two opportunities need not be wasted.

The paper brought into perspective the analytical and empirical literature that seemingly told inconsistent stories on Africa's prospects. The empirical growth literature based on cross-country data generally could not establish the long held view that Africa had adverse initial conditions that keep it locked in a poverty trap. While this narration may fit into the growth spurt that has been observed in the last decade, another strand of literature brought out a powerful result that high initial poverty is bad for growth, which also echoes the findings that high initial inequality is bad for growth (e.g. Fosu, 2010). This link between poverty and growth is also consistent with the findings of micro-studies that investigated for the existence of multiple equilibriums using longitudinal data for selected African countries. There are large segments of Africa's population for whom staying poor for an extended period of time has become the fate of life. Such phenomenon of low productivity in the subsistence and informal sector, coexisting with dynamic, rapidly growing modern sector is responsible for the weak link between average growth and poverty reduction. 
The dual economic structure typical of most low income African countries call for a policy paradigm that improves both economic fundamentals at the macro level and concerted efforts to speed up structural transformation at sectoral and micro level (e.g. Monga, 2013; Rodrik, 2013). There has been much improvement in Africa over the past years in areas of market-led economic reform that included privatization, liberalization and stabilization. While important, these policy measures are not sufficient to spur structural transformation that allows people to move from low to high productivity sector, and thus reduce poverty significantly. The experiences of developing countries suggest that structural change is more powerful than average growth in per capita GDP to bring about meaningful impact on poverty. The range of policy measures needed to achieve such transformation varies with the specific context prevailing in each country, but one thing is clear. Without structural transformation, accompanied by ongoing reforms to improve economic fundamentals, current growth would eventually peter out or slow down significantly. Some African countries that have started, but slowed down the path towards modernizing their economy through continuous dialogue with the private sector may have to reconsider resuming this practice and others to follow suit as these forums provide practical guide on what is needed by investors and entrepreneurs to move the agenda forward. Commitment to reform the educational and health care system, particularly for the poor and vulnerable; and facilitating financial and technical support to farmers and small-business, need to be backed by meaningful action, and experiment of new ideas and innovations. 


\section{References}

African Economic Outlook, (2012), "Promoting youth employment", a publication of AfDB, OECD, UNECA, UNDP.

Alkire, Sabina \& Foster, James, 2011. "Counting and multidimensional poverty measurement," Journal of Public Economics, Elsevier, vol. 95(7-8), pages 476-487, August.

Alesina, A \& Easterly, W. \& Matuszeski, J (2011). "Artificial States," Journal of the European Economic Association, European Economic Association, vol. 9(2), pages 246-277, 04.

Andrimihaja, N. A. , Matthias Cinyabuguma, and Shantayanan Devarajan, (2012), "Avoiding the fragility trap in Africa", Working Paper Series, 5884, World Bank

Azariadis, C. and Stachurski, J (2005). Poverty Traps. Handbook of Economic Growth, Volume 1A, Elsevier B.V.

Barnett, J.B.and Barrett, B.C.(2008). Poverty Traps and Index-Based Risk Transfer Products World Development 36,10,1766-1785

Barrett, B.C and Swallow, Brent M. (2006). Fractal Poverty Traps. World Development 34, 1,115

Beegle, K, De Weerdt, J, Friedman, J and , Gibson, J. (2012)"Methods of household consumption measurement through surveys: Experimental results from Tanzania”, Journal of Development Economics, 98 (2012) 3-18

Berthelemy J., (2006), Convergence and Development Traps, How did emerging economies escape the under-development trap?, Growth and integration - Annual World Bank Conference on Development Economics, François Bourguignon, Boris Pleskovic (Ed.) p. 127 pages-157 pages

Bigsten, A and Shimeles, A (2008)"Poverty transition and persistence in Ethiopia" World Development, vol. 36(9), pages 1559-1584, September

Bigsten, A. and Shimeles, A (2006), “Can Africa reduce poverty by half by 2012?”, Development Policy Review, vol 25(2): 147-166

Booysen, F.,Servaas Van der berg, Burger, R.and Maltitz, V.M.(2008). Using an Asset Index to Assess Trends in Poverty in Seven Sub-Saharan African Countries. World Development ,36, $6,1113-1130$

Bourguignon, F. (2002), "The poverty-growth-inequality triangle”, World Bank, Washington DC 
Carter, R.M., Little, D.P, Mogues, T.(2007). Poverty Traps and Natural Disasters in Ethiopia and Honduras. World Development 35, 5,835-856,

Cazzavillan, G., Donadelli, M., Persha , 1.(2013). Economic growth and poverty traps in subSaharan Africa: The role of education and TFP shocks. Research in Economics ,67, 226-242

Collier, P,, (2004), “Conflict and development', Center for the Study of African Economies, Oxford University, memo

Deaton, A. (2005), "Measuring poverty in a growing world (or measuring growth in a poor world), NBER Working Paper Series, WP 9822

Dercon, S.(1998). Wealth, risk and activity choice: cattle in Western Tanzania. Journal of Development Economics,55, 1-42

Dercon, S. (2006). Economic reform, growth and the poor: Evidence from rural Ethiopia. Journal of Development Economics 81, 1 - 24

Dercon, S., and Christiaensen, L.,(2011). Consumption risk, technology adoption and poverty traps: Evidence from Ethiopia Journal of Development Economics 96 (2011) 159-173

Dollar, David \& Kraay, Aart, (2002). " Growth Is Good for the Poor," Journal of Economic Growth, Springer, vol. 7(3), pages 195-225, September

Deverajan, S (2013). “Africa's statistical tragedy", the review of income and wealth, DOI: 10.111/roiw.12013

Easterly, W. (2006). Reliving the 50s: the Big Push, Poverty Traps, and Takeoffs in Economic Development. NYU

Fosu, A.,(2010). Does inequality constrain poverty reduction programs? Evidence from Africa. Journal of Policy Modeling 32, 818-827

Fosu, A (2009), "Impacts of Policy Syndromes and Governance on Productivity and Growth of African Economies" Seminar presentation at Center for the Study of African Economies, Oxford University

Ghiglino, C. and Sorger, G.(2002). Poverty Traps, Indeterminacy, and the Wealth Distribution. Journal of Economic Theory 105, 120-139

Giesbert, L., and Schindler, K.,(2012). Assets, Shocks, and Poverty Traps in Rural Mozambique. World Development 40, 8,1594-1609

Goodhand, J. (2003).Enduring Disorder and Persistent Poverty: A Review of the Linkages Between War and Chronic Poverty. World Development , 31, 3, 629-646 
Hausmann, R., L. Prichett, L and D. Rodrik, (2005), “Growth accelerations”, Harvard University.

Kalwij, A. and Verschoor, A. (2007) .Not by growth alone: The role of the distribution of income in regional diversity in poverty reduction. European Economic Review 51, 805-829

Kraay, A. and Raddatz, C.(2007). Poverty traps, aid, and growth. Journal of Development Economics 82, 315-347

McKay, A. (2013), "Growth and poverty reduction in Africa: evidence from AERC growthpoverty project and beyond", AERC, Nairobi, Kenya

McKay, A and Perge, E. (2011), "How strong is the evidence for the existence of poverty traps? A multi country assessment”, Economics Department Working Paper Series: 25-2011, University of Sussex

McKinsie (2010), “Lion's on the move”, www.mckinsey.com/insights/africa/lions_on_the_move

McMillan, M. (2013), "Structural Change in Africa: Harnessing Natural Resources for Inclusive Growth” African Development Bank.

Monga, C. (2013), "The Mechanics of Job Creation: Seizing the New Dividends of Globalization", World Bank Working Paper Series, WP 6661.

Moradi, A., and Baten, J.,(2005). Inequality in Sub-Saharan Africa: New Data and New Insights from Anthropometric Estimates. World Development 33, 8 1233-1265

Naschold, F.(2012). “The Poor Stay Poor": Household Asset Poverty Traps in Rural Semi-Arid India. World Development 40,10, 2033-2043

Ncube, M and Shimeles, A. (2013), "The making of middle class in Africa: evidence from DHS data", IZA Discussion Papers, 7352, IZA

Nunn N (2008). "The Long-Term Effects of Africa's Slave Trades," The Quarterly Journal of Economics, MIT Press, vol. 123(1), pages 139-176, 02.

Larke and Milanovic, (2013), "Global Income Distribution: From the fall of the Berlin Wall to the Great Recession”, World Bank Working Paper Series, 6719

Li, J and C. Monga (2011), "Growth identification and facilitation: the role of the state in the dynamics of structural change", Development Policy Review, 2011: 264-290.

Lopez, H. and Servén, L., (2009).Too Poor to Grow. Policy Research Working Paper 5012 ,The World Bank. 
Lopeza, M.S, Molerob,J.and Santos-Arteaga, J.F.(2011). Poverty traps in a frictionless world:

The effects of learning and technology assimilation. Structural Change and Economic Dynamics $22,106-115$

Page, J. (2013), "Industrial policy in practice in Africa”, African Development Bank

Page, J and Shimeles, A (2013), “Aid, employment and poverty in Africa”, African Development Bank

Paternostro, S. (1997)The Poverty Trap: The Dual Externality Model and Its Policy Implications. World Development, 25, 12, 207 1-208 I

Pinkovskiy, M and Xavier Sala-i-Martin (2014), "Lights, Camera,.. Income: estimating poverty using national accounts, survey means and lights” NBER Working Paper Series, 19831

Pinkovskiy, M and Xavier Sala-i-Martin (2013), "Africa is on time”, processed. Colombia University.

Radeny,M., Marrit Van Den Berg and Schipper,B. (2012)Rural Poverty Dynamics in Kenya: Structural Declines and Stochastic Escapes. World Development 40 8,1577-1593

Ravallion, M. (2012). "Why Don't We See Poverty Convergence?," American Economic Review, American Economic Association, vol. 102(1), pages 504-23, February.

Rodrik, D(2013), "Structural change, fundamentals, and growth: an overview”, Princeton University, September

Sachs, J and Warner, A (1997), "Sources of Slow Growth in African Economies," Journal of African Economies, vol. 6 no. 3,

Sachs, J. ,John W. Mcarthur, Guido schmidt-traub, Margaret kruk, Chandrika Bahadur, Michael Faye, and Gordon Mccord (2007). Ending Africa's Poverty Trap. Brookings Papers on Economic Activity,

Sahn, E.D. and Stifel, C.D.(2000). Poverty Comparisons Over Time and Across Countries in Africa. World Development 28, 12, 2123-2155

Santos, P. and Barrett, C.(2011). Persistent poverty and informal credit. Journal of Development Economics 96 , 337-347

Shimeles, A. and Thorebecke, E. (2014), "Does initial poverty bad for growth in Africa?: a revisit", African Development Bank. forthcoming

Stiglitz, J, J.Y, Li, and C. Monga (2013), “The rejuvenation of industrial policy”, World Bank Working Paper Series, 6628, World Bank, Washington DC

Takayama, N. (1979), "Poverty, Income Inequality and their measures: Professor Sen's Axiomatic approach reconsidered", Econometrica, 47: 747-59. 
The Economist (2013), "Emerging Africa: the hopeful continent", March

The Economist (2011), "The hopeful continent: Africa rising”, December

The Economist (2001), “Hopeless Africa”, March

UNECA (1999), “African Economic Report”, Addis Ababa, Ethiopia

Young, Alwyn, (2012) The African Growth Miracle . NBER Working Paper No. w 18490. 
Table 1: Initial per capita GDP and growth in Africa

\begin{tabular}{|c|c|c|c|c|c|c|}
\hline & $\begin{array}{c}\text { Absolute } \\
\text { Poverty trap } \\
1962-2011\end{array}$ & $\begin{array}{c}\text { Relative } \\
\text { poverty trap } \\
1962-2011\end{array}$ & $\begin{array}{c}\text { Absolute } \\
\text { Poverty trap } \\
1962-1995\end{array}$ & $\begin{array}{c}\text { Relative } \\
\text { poverty trap } \\
1962-1995\end{array}$ & $\begin{array}{c}\text { Absolute } \\
\text { Poverty trap } \\
\text { 1995-2011 }\end{array}$ & $\begin{array}{c}\text { Relative } \\
\text { poverty trap } \\
1995-2011\end{array}$ \\
\hline $\begin{array}{l}\text { Dummy for poorest } \\
\text { quintile }\end{array}$ & 0.0117 & 0.0117 & 0.0128 & 0.0128 & 0.0090 & 0.0090 \\
\hline std error & 0.0031 & 0.0033 & 0.0042 & 0.0044 & 0.0039 & 0.0041 \\
\hline t-stat & 3.7275 & 3.5885 & 3.0278 & 2.9043 & 2.2907 & 2.1886 \\
\hline $\begin{array}{c}\text { Constant (per capita } \\
\text { growth of upper } 4 \\
\text { quintiles) }\end{array}$ & 0.0095 & -0.0002 & 0.0045 & -0.0003 & 0.0195 & 0.0004 \\
\hline std Error & 0.0016 & 0.0017 & 0.0020 & 0.0021 & 0.0025 & 0.0026 \\
\hline t-stat & 6.0411 & -0.1078 & 2.2876 & -0.1631 & 7.7850 & 0.1509 \\
\hline Observations & 2058 & 2009 & 1386 & 1353 & 714 & 697 \\
\hline $\mathrm{F}(1, \mathrm{~N}-2)$ & 13.89 & 12.8800 & 9.17 & 8.43 & 5.25 & 4.79 \\
\hline Prob $>$ F & 0.0002 & 0.0003 & 0.0025 & 0.0037 & 0.0223 & 0.029 \\
\hline R-squared & 0.006 & 0.0057 & 0.0066 & 0.0062 & 0.0044 & 0.0042 \\
\hline Root MSE & 0.062 & 0.0641 & 0.0646 & $\begin{array}{c}0.0672 \\
9\end{array}$ & 0.05539 & 0.05729 \\
\hline Countries & 42 & 41 & 42 & 41 & 42 & 41 \\
\hline $\begin{array}{l}\text { Reject stationary income } \\
\text { for poorest fifth }\end{array}$ & Yes & & Yes & & Yes & \\
\hline
\end{tabular}

Source: author's computation based on Penn World Tables.

Table 2: Transition matrix by wealth status for African countries

\begin{tabular}{|c|c|c|c|c|}
\hline & $5-2011$ & & & \\
\hline Pre 1995 & Poor & Middle class & Upper class & Total \\
\hline Poor & 95.61 & 4.39 & 0 & 100 \\
\hline Middle class & 2.33 & 69.77 & 27.91 & 100 \\
\hline Upper class & 0 & 0 & 100 & 100 \\
\hline Total & 87.5 & 8.81 & 3.69 & 100 \\
\hline
\end{tabular}

Source: computations by Ncube and Shimeles (2013) based on DHS data for 35 African countries

Table 3: Multidimensional asset poverty for selected African countries

\begin{tabular}{|c|c|c|c|c|c|c|}
\hline Period & $\begin{array}{l}\text { Number of } \\
\text { countries }\end{array}$ & $\begin{array}{l}\text { Population } \\
\text { coverage }(\%)\end{array}$ & $\begin{array}{l}\text { Asset poverty } \\
(\%) \\
\text { (Median, un- } \\
\text { weighted) }\end{array}$ & $\begin{array}{l}\text { Asset } \\
\text { poverty (\%) } \\
\text { (Median, } \\
\text { weighted) }\end{array}$ & $\begin{array}{l}\text { Asset poverty } \\
(\%) \\
\text { (mean, un- } \\
\text { weighted) }\end{array}$ & $\begin{array}{l}\text { Asset } \\
\text { poverty } \\
(\%) \\
\text { (Mean, } \\
\text { weighted) }\end{array}$ \\
\hline 1990-1994 & 16 & 42.5 & 36.5 & 41.3 & 38.7 (15.7) & $40.6(14.0)$ \\
\hline 1995-1999 & 22 & 47.9 & 27.1 & 24.4 & $27.7(17.9)$ & $21.0(18.2)$ \\
\hline
\end{tabular}




\begin{tabular}{lllllll}
\hline $2000-2004$ & 18 & 56.4 & 26.1 & 19.1 & $28.4(20.4)$ & $25.8(27.2)$ \\
$2004-2011$ & 24 & 63.5 & 25.8 & 26.3 & $26.1(15.4)$ & $27.8(20.4)$ \\
\hline
\end{tabular}

Source: author's computations from 82 country-year matched Demographic and Health Survey waves 
Table 4: Decomposition of poverty by sector of employment in Africa

\begin{tabular}{ll}
\hline Sector of employment & $\%$ \\
\hline Agriculture & 54 \\
Industry & 12 \\
Services & 31 \\
Residual & 3 \\
Total & 100 \\
\hline
\end{tabular}

Source: author's computation based on recent 26 household surveys (2005 and latest) for 18 African countries

Table 5: Two Step GMM Estimate of the Relationship between Poverty and Sectoral Shares of Employment

\begin{tabular}{lcrrr}
\hline Dependent variable (Log headcount ratio) & All Developing Countries & \multicolumn{2}{r}{ Africa Sample } \\
\hline & Coef. & $\mathrm{Z}$ & Coef. & $\mathrm{Z}$ \\
Log share of labor in agriculture & 0.05 & 0.19 & $1.23^{*}$ & 1.95 \\
Log share of labor in industry & $-0.79 * *$ & -2.87 & -0.29 & -0.37 \\
Log share of labor services & -0.61 & -0.58 & $1.29 *$ & 1.94 \\
Log consumption & $-0.30^{* *}$ & -2.44 & $-1.12^{* *}$ & -2.14 \\
Log gini coefficient & $2.52^{* * *}$ & 6.34 & $2.77^{* * *}$ & 4.61 \\
Constant & -0.94 & -0.34 & -10.54 & -2.08 \\
Sargan's statistic (over- identification test & 0.8492 & & 0.3464 & \\
Number of observations & 328 & \multicolumn{3}{c}{58} \\
\hline
\end{tabular}

${ }^{* * *}$ significant at $1 \% ;{ }^{* *}$ significant at $5 \% ;{ }^{*}$ significant at $10 \%$

Source: Page and Shimeles (2013)

Figure 1: trends in extreme poverty by region

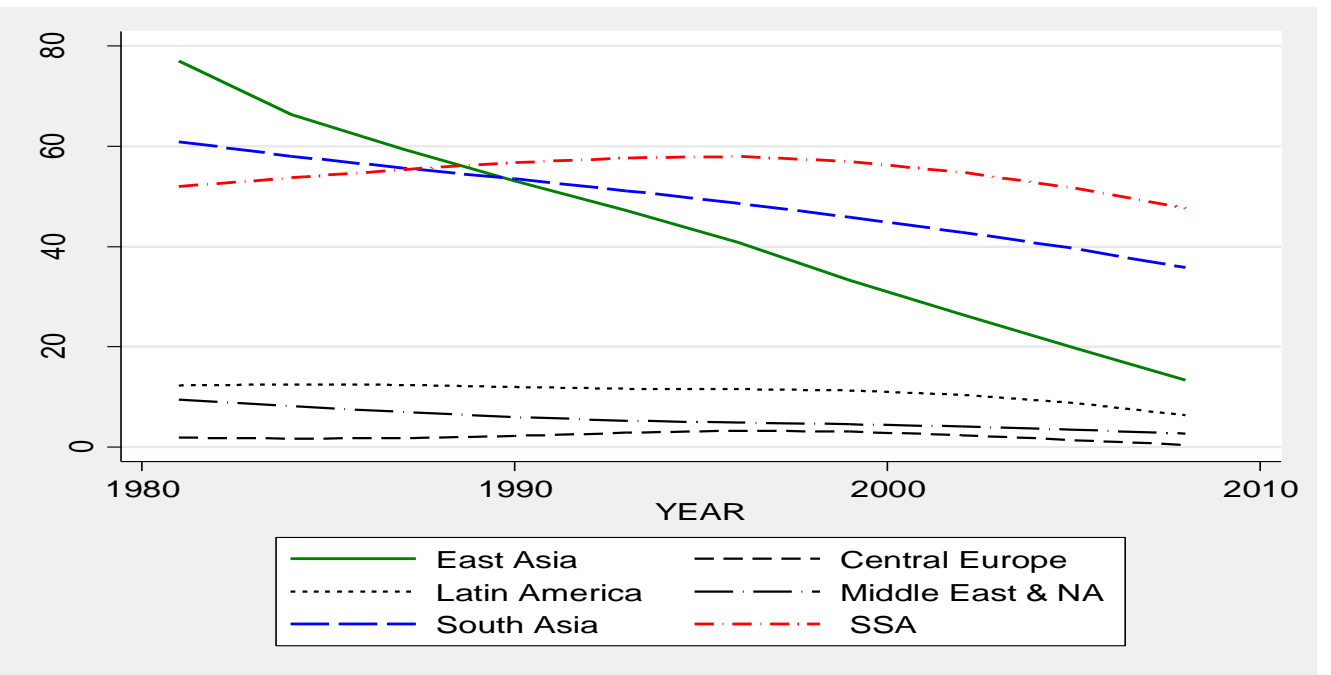


Source: author's computation from data provided in www.povcalnet.org.

Figure 2: Log Per capita GDP and per capita GDP growth for Africa: 1960-2011

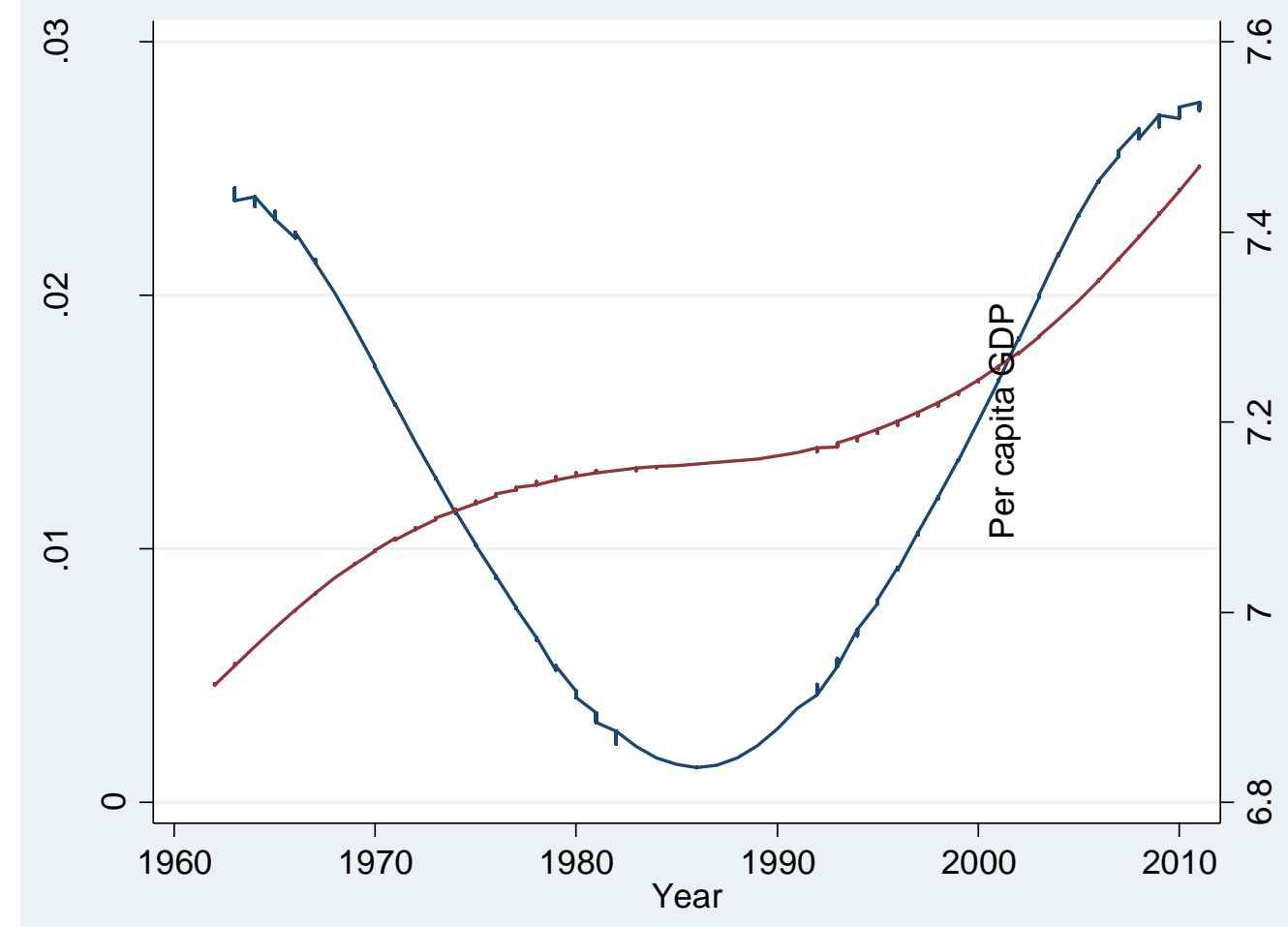

Source: author's computation based on data from Penn World Tables 
Figure 3: Lowess estimate of Proportion of African countries with at least one growth acceleration (Penn World Tables: $\mathrm{N}=48$ )

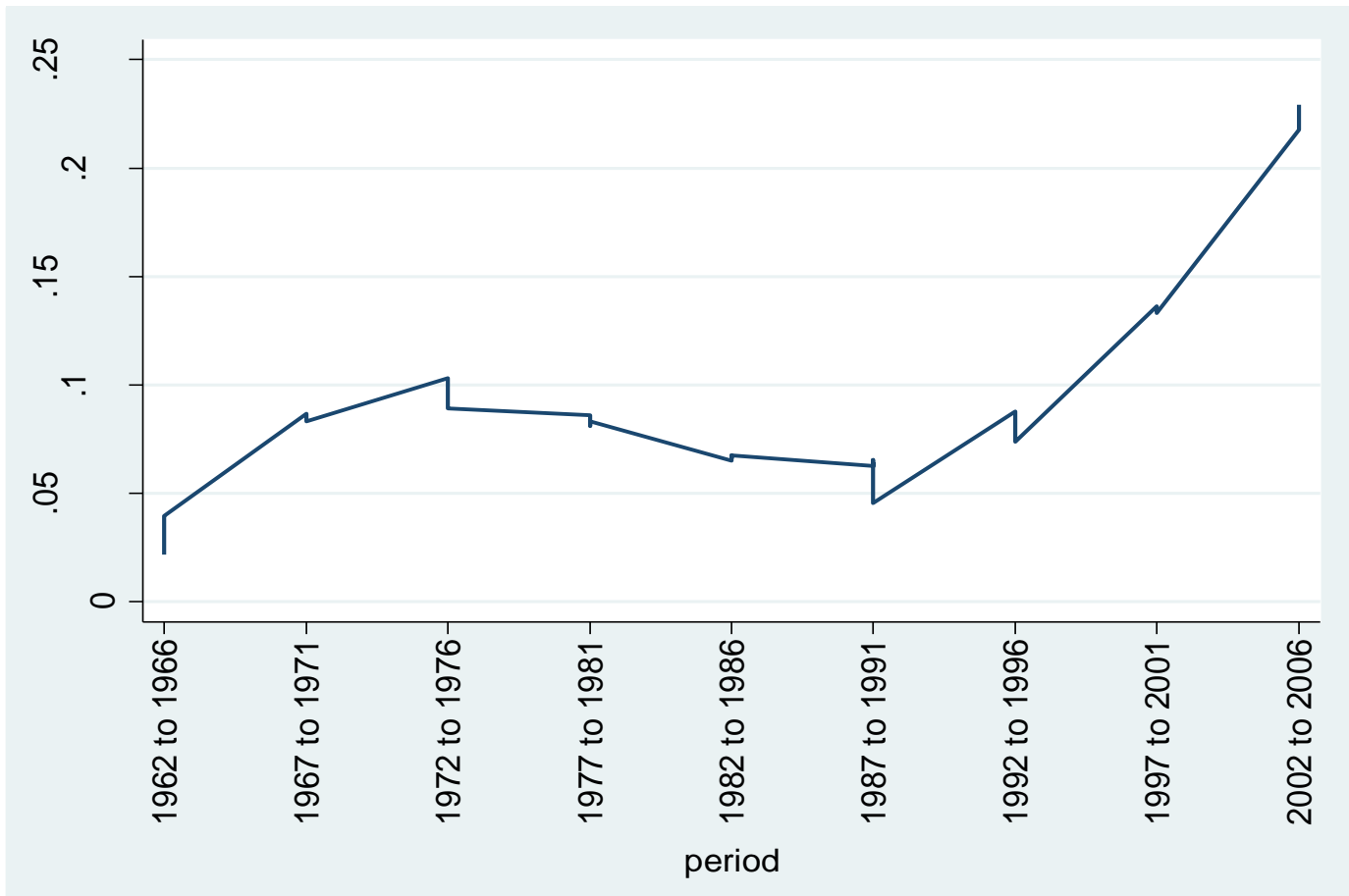

Figure 4: Change in middle class status on the basis of household wealth/asset for selected African countries during 1990s-2010

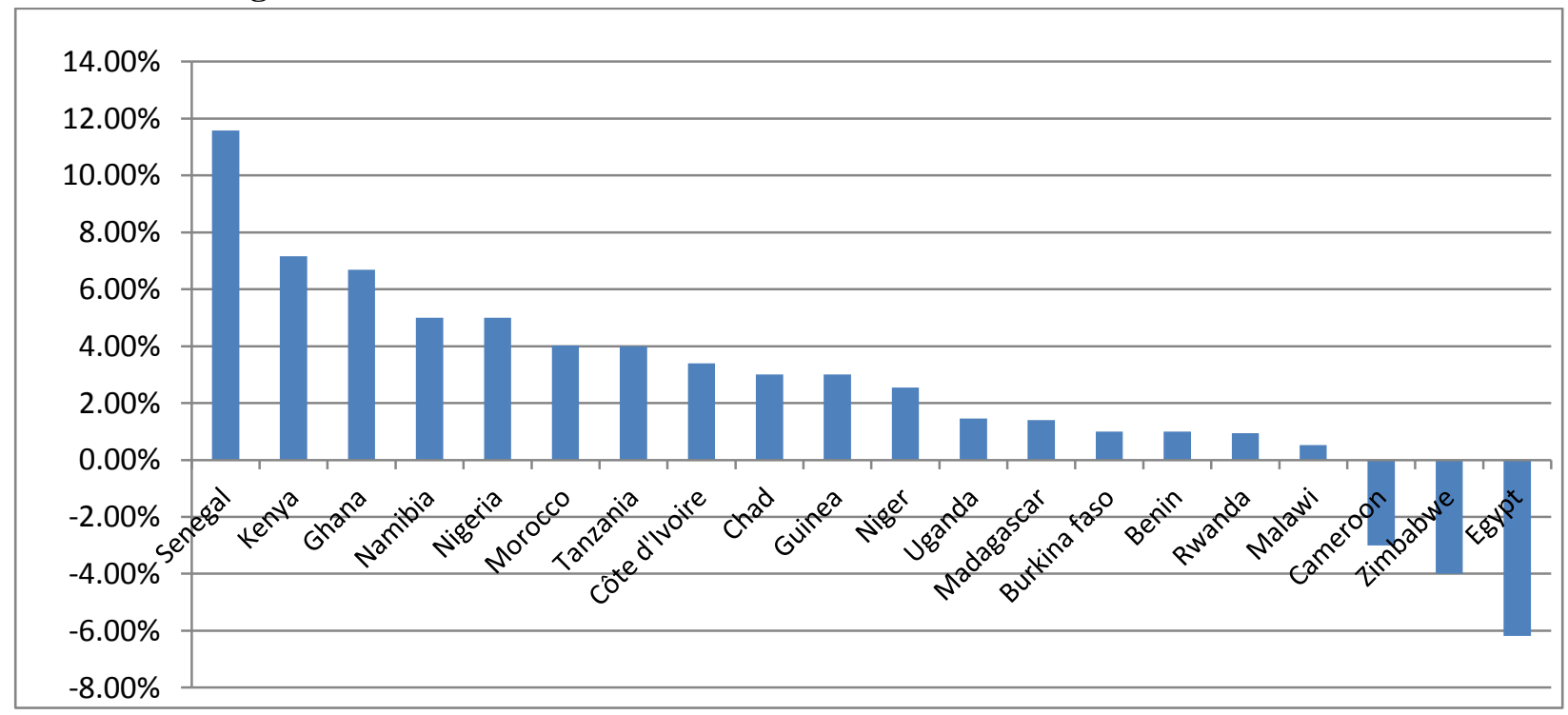


Figure 5: Multidimensional Asset-based poverty and per capita GDP for selected countries in Africa

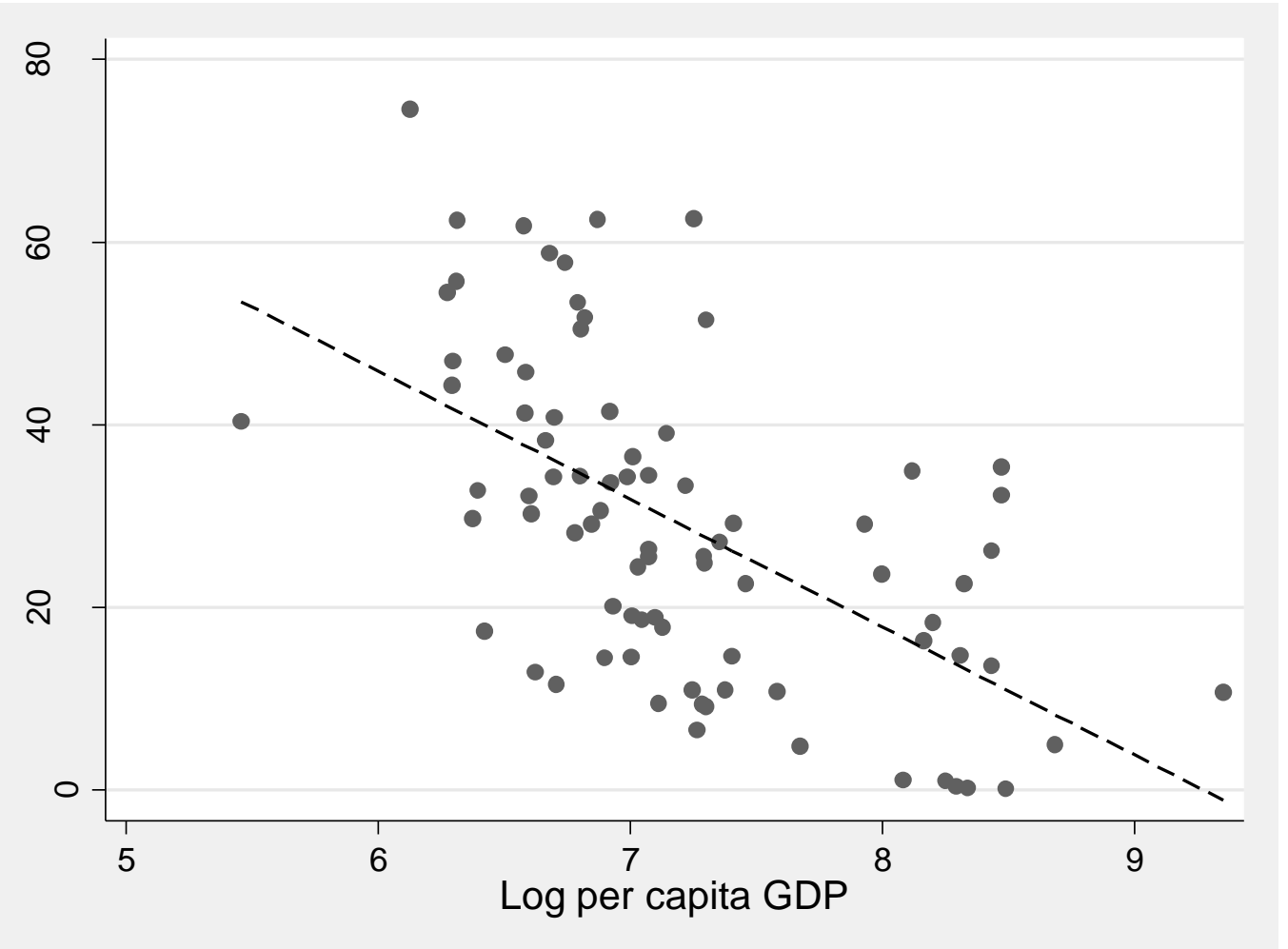

Source: author's computations

Figure 6: Poverty in agriculture, services and industry sectors by the level of aggregate poverty

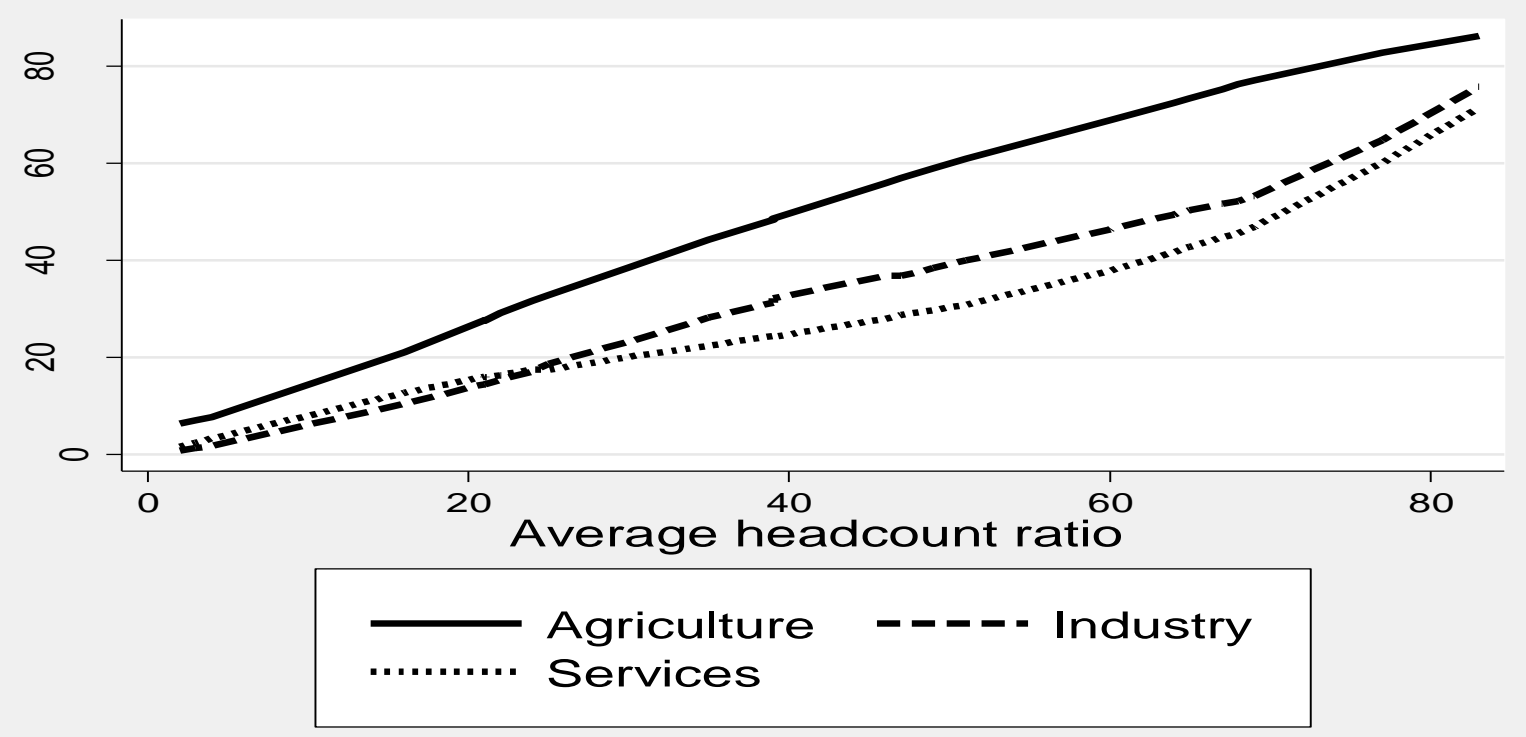

Source: author's computations 
Figure 7: Gini index for asset (wealth) and educational achievements for selected African countries

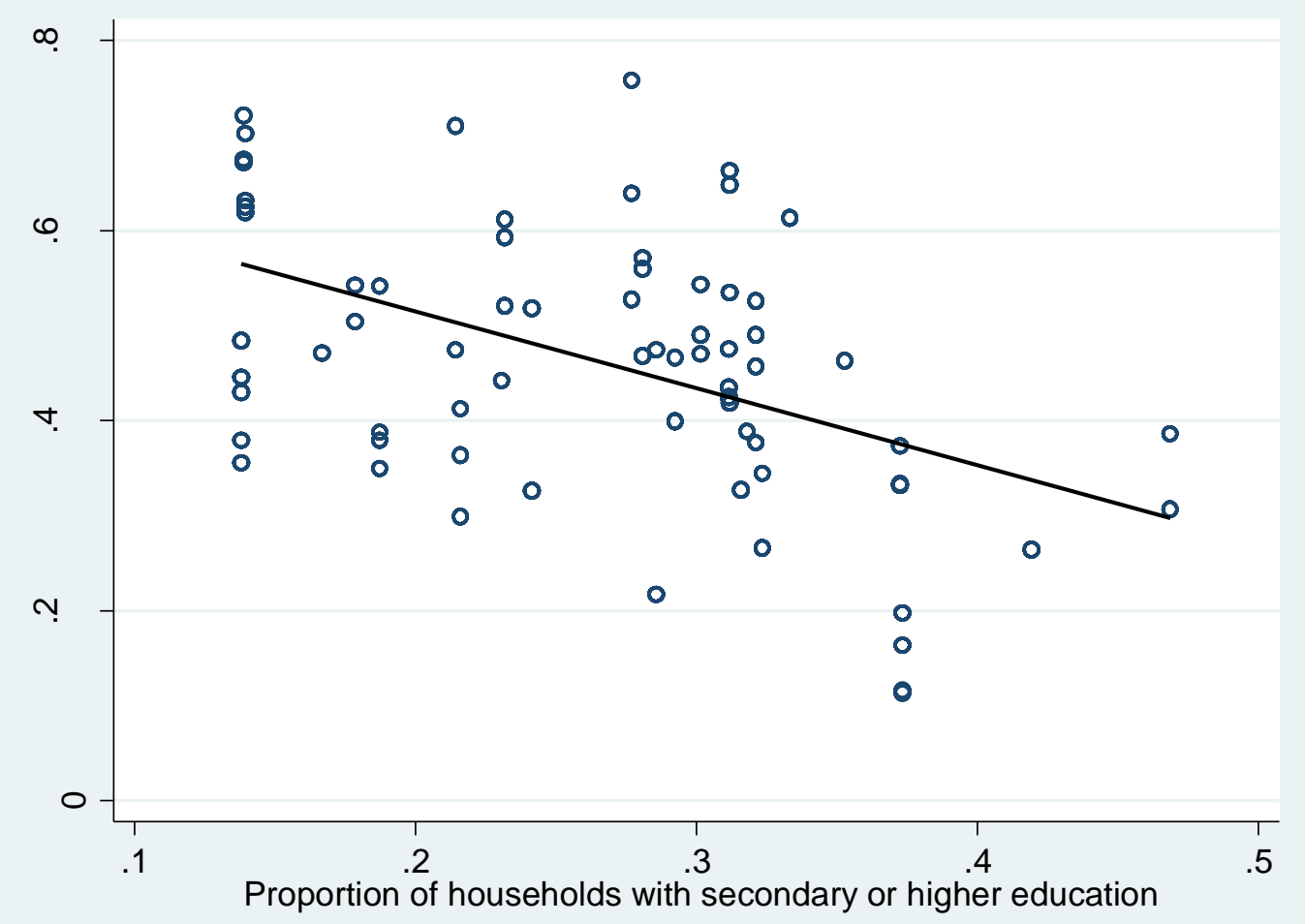

Source: computations based on unit record data from DHS for 82 country-year matched data. 